256 | InterAção

\title{
HEGEMONIA E CONTESTAÇÃO: A APROXIMAÇÃO DE CAETANO VELOSO À TEORIA CRÍTICA COXIANA ${ }^{1}$
}

\author{
Junior Ivan Bourscheid ${ }^{2}$
}

\section{Resumo}

Neste estudo se efetuará a análise de quatro canções de Caetano Veloso relativas ao período dos anos 1990 e 2000, evidenciando sua contribuição para a compreensão das relações internacionais deste período, com enfoque nas temáticas centrais apresentadas pelo artista nas canções. Elucidar-se-á a crítica de Caetano ao projeto hegemônico estadunidense, aportando seus desafios e limites que, quando confrontados definitivamente, resultaram na

\footnotetext{
10 estudo é parte da monografia de conclusão de curso apresentada no curso de Relações Internacionais da Universidade Federal de Santa Maria, em 20 de dezembro de 2013, orientada pelo Prof. Dr. José Renato Ferraz da Silveira. A monografia completa intitula-se "Hegemonia e Contestação: uma análise da contribuição de Caetano Veloso para a percepção do Sistema Internacional pósGuerra Fria (1991-2001)", sendo o fragmento aqui apresentado o terceiro capítulo da monografia.

2 Mestrando do Programa de Pós-Graduação em Ciência Política da Universidade Federal do Rio Grande do Sul; Graduado em Relações Internacionais pela Universidade Federal de Santa Maria (2014); Pesquisador membro do Núcleo de Pesquisas em Relações Internacionais de Santa Maria (PRISMA); $2^{\circ}$ Secretário do Centro de Integração Latino Americana (CILAM). E-mail: junior_bourscheid@hotmail.com
} 
257 | InterAção

transformação do modo de atuação dos Estados Unidos, recorrendo aos meios coercitivos para a manutenção do Sistema Internacional. Portanto, ao realizar tais análises, intenta-se aproximar as contribuições de Caetano Veloso para a percepção dos fenômenos internacionais com os apontamentos da teoria crítica coxiana, compreendendo sua lógica hegemônica e fornecendo alternativas viáveis para a solução das problemáticas humanas centrais que permeiam tal contexto.

Palavras-chave: Hegemonia. Pós-Guerra Fria. Contestação. Caetano Veloso. Teoria Crítica.

\begin{abstract}
This study will perform an examination of four songs by Caetano Veloso for the period of 1990 and 2000, demonstrating its contribution to the understanding of international relations in this period, focusing on the central themes presented by the artist in these songs. It will elucidate the critical Caetano to the U.S. hegemonic project, bringing its challenges and limitations that when faced definitely resulted in the transformation of the mode
\end{abstract}


of action of the United States, resorting to coercion means to maintain the International System. Therefore, when performing such analyzes, intends to approach the contributions of Caetano Veloso for the perception of international phenomena with notes of coxian critical theory, including its hegemonic logic and providing viable alternatives for the solution of the central human issues that permeate this context.

Keywords: Hegemony. Post Cold War. Contestation. Caetano Veloso. Critical Theory.

\section{INTRODUÇÃO}

Considerando as várias nuances conceituais que permeiam o campo de estudo das relações internacionais, este estudo parte da premissa de Robert Cox (1986) de que toda teoria "é para algo e para alguém". No ímpeto de analisar as relações internacionais da década de 1990, apreciando o processo de desenvolvimento histórico que lhe aportou algumas de suas linhas de desenvolvimento, bem como suas consequências para o período seguinte, 
259 | InterAção

encontra-se na conceituação coxiana dos fenômenos internacionais uma coerente ferramenta analítica.

Neste escopo, é fundamental elucidar o conceito de hegemonia, categoria que instiga as análises coxianas desde os anos oitentas, tendo sua raiz intelectual no cientista político italiano Antonio Gramsci. A relação de hegemonia é contemplada enquanto relação pedagógica, verificável tanto interna quanto internacionalmente, envolvendo as diversas forças sociais relativas ao âmbito nacional, bem como os "conjuntos de civilizações nacionais e continentais" (GRAMSCI, 1978: 37).

A hegemonia mundial é descritível como uma estrutura social, (...) econômica, e (...) política, e não pode ser simplesmente uma dessas coisas (...). A hegemonia mundial, além disso, é expressa em normas universais, instituições e mecanismos que estabelecem regras gerais de conduta para os Estados e para as forças da sociedade civil que atuam além das fronteiras nacionais - regras que apóiam o modo de produção dominante (COX, 1993: 62).

No entanto, para se estabelecer enquanto hegemonia mundial, o projeto da nação dominante deve comportar um tênue jogo de pressões sobre sua atuação 
externa, opondo-se o consenso à coerção, fatores imprescindíveis ao exercício da hegemonia. "Na medida em que o aspecto consensual de poder está na vanguarda, a hegemonia prevalece. A coerção é sempre latente, mas só é aplicada em casos marginais, desviantes" (COX, 1993: 52). Ao projeto hegemônico é indispensável a capacidade de universalização, pelo que é forçoso adequar seus interesses e pretensões individuais em ideias, ideologias, valores, normas e instituições que abarquem a complexidade de interesses sob o marco dos distintos atores internacionais. "Esse marco tem a forma de uma estrutura histórica, uma combinação particular de modelos de pensamento, condições materiais e instituições humanas que tem certa coerência entre seus elementos"' (COX, 1986: 141).

Com tais perspectivas, este estudo empreende a análise interna de quatro canções de Caetano Veloso (Fora da Ordem; Santa Clara, padroeira da televisão; O Herói; A Base de Guantánamo) que compreendem fenômenos das relações internacionais da década de 1990, e suas implicações na posterior década de 2000. Seguindo a senda da teoria crítica coxiana, a arte crítica de Caetano Veloso logra 
261 | InterAção

difundir por meio de sua produção artística a contestação da ordem vigente, que durante os anos noventas esteve fundada na tentativa de instalação de um ordenamento internacional hegemônico, sob preponderância estadunidense.

\section{ALGUMA COISA ESTÁ FORA DA NOVA ORDEM MUNDIAL}

O desfecho do período bipolar das relações internacionais trouxe consigo uma ampla gama de dilemas e desafios para os analistas e policymakers. Resgatando o aporte de Gramsci e Cox concebe-se que, sob esse panorama, emergiram perspectivas analíticas fundadas na necessidade do projeto hegemônico de permear-se de elementos universalizantes, a fim de obter a aquiescência dos dominados, prescindindo do fator coercitivo, renegado às situações marginais e desviantes.

Não obstante, observa-se um marcado dissenso entre tais abordagens, fundadas em concepções diametralmente opostas dos fenômenos centrais para a percepção das relações internacionais no pós-Guerra Fria, 
bem como nas possíveis implicações que tais fenômenos aportariam ao desenvolvimento histórico da humanidade. Dentro dos limites inerentes a este trabalho, focamos em dois grupos de teorias, e seus principais baluartes, a fim de expor e analisar suas contribuições para o discernimento dos arranjos de poder prevalecentes no período estudado: o otimismo provindo do triunfo do capitalismo na disputa bipolar, tendo seu principal expoente na teoria do "fim da história" de Francis Fukuyama, e o pessimismo com o aprofundamento das tensões reprimidas pela lógica estruturante do período anterior, exemplificada na teoria do "choque de civilizações" de Samuel Huntington.

Contudo, numa observação geral de ambos os argumentos sobressalta-se a compactuação quanto a existência de uma civilização ou sociedade ocidental homogênea, "fechada” (VELOSO, 1997), base para as duas teorias. Enquanto uma concebe a imprescindibilidade da difusão dos elementos estruturantes desta sociedade como modelo universal visando a estabilização das relações humanas, a outra atenta à necessidade de proteção dessa civilização num mundo intercivilizacional crescentemente 
263 | InterAção

conflituoso. "As perspectivas tanto de Fukuyama quanto de Huntington padecem de tentar encaixar o mundo pósGuerra Fria em um ou outro padrão. No entanto, não se pode falar em um padrão único que sirva para todos" (NYE, 2009, p. 314).

E é justamente nesse "fechamento" da cultura ocidental proposta pelas teorias universalizantes onde encontramos a base do inconformismo de Caetano, expresso em sua recusa da "nova ordem". O artista reconhece os fatores estruturantes de tal ocidentalismo, presente tanto em Huntington (1997), quanto em Fukuyama (2007). “Foi no Ocidente que se desencadeou um processo de secularização do conhecimento que resultou na ciência de eficácia universal tal como a conhecemos, e na moral individualista ateia em que se baseiam os 'direitos humanos'” (VELOSO, 1997, p. 345).

Portanto, Caetano lança-se ao esforço de contrapor a categorização civilizacional, suas limitações intrínsecas, propondo uma abordagem paralela às considerações de Huntington (1997), que levasse em conta o vasto rol de nuances presentes no seio das civilizações propostas pelo autor. Inquieta-se, do mesmo modo, com o pretenso 
triunfo do capitalismo liberal e sua extensão inevitável a toda humanidade. Caetano preocupava-se em caracterizar "um Ocidente ao ocidente do Ocidente".

\begin{abstract}
E quando falo, a esse respeito, de "um Ocidente ao ocidente do Ocidente", penso não num fundamentalismo dessa cultura particular, mas no compromisso com alguns conseguimentos historicamente ocidentais irreversíveis, Takeshi Umehara (citado por Huntington) escreveu que "o completo fracasso do marxismo e o espetacular esfacelamento da União Soviética são apenas os precursores do colapso do liberalismo ocidental, a principal corrente da modernidade. Longe de ser a alternativa do marxismo e a ideologia dominante no final da História, o liberalismo será a próxima pedra de dominó a cair". Essa observação leva Huntington a sugerir a união estratégica dos Estados Unidos com os países europeus "cristãos" (VELOSO, 1997, p. 345).
\end{abstract}

Tendo em conta as pretensões explicativas das teorias surgidas no centro hegemônico, Caetano Veloso lança-se à crítica e ao questionamento da aplicabilidade de tais aportes. Tanto o otimismo liberal quanto o pessimismo civilizacional comprometiam-se com a universalização de fenômenos específicos, referentes aos 
265 | InterAção

processos mais recentes do desenvolvimento histórico. De tal forma, se efetivamente estávamos adentrando em uma "nova ordem mundial", onde estaria o Brasil nesta ordem?

No disco Circuladô, o que parece estar deslocado é novamente o lugar: o Brasil, visto como um estrangeiro diante do quadro restritivo de uma "nova ordem mundial". O que não quer dizer que o mal-estar ante o neoconservadorismo dos novos tempos tenha sido apaziguado. Ao contrário, o sujeito indeterminado ("alguma coisa") que na canção "Fora da Ordem" aparece como estando deslocado - em que adivinhamos a referência ao Brasil -, nada mais é do que uma extensão coletiva (cultural, geográfica) [...], representa um aprofundamento de sua fratura, mirando a falta de lugar definido para um país como o Brasil no cenário de uma globalização excludente, que o presidente americano George Bush (pai) havia chamado de "nova ordem mundial" (WISNIK, 2005, p. 20).

Caetano empenhava-se na desconstrução dos mitos que permeavam o projeto hegemônico. Para tanto, utilizava-se da exposição do caso brasileiro, suas conjunturas específicas e a interação destas com a estrutura histórica presente, a fim de elucidar os limites que as abordagens dominantes impunham à análise do 
novo momento histórico. “Eu sei o que é bom/ Eu não espero pelo dia em que todos os homens concordem/ Apenas sei de diversas harmonias bonitas possíveis sem juízo final" (VELOSO, 1991). Assim:

$$
\begin{aligned}
& \text { [...] em meados dos anos } 80 \text { dá-se uma } \\
& \text { importante guinada na obra de } \\
& \text { Caetano em direção a uma nova } \\
& \text { focalização temática do Brasil - tanto } \\
& \text { como afirmação de um potencial } \\
& \text { singular-construtivo contido na sua } \\
& \text { riqueza cultural quanto como } \\
& \text { acusação da miséria de sua realidade } \\
& \text { social urbana. Há, portanto, um } \\
& \text { retensionamento da relação de suas } \\
& \text { canções com o país [...] (WISNIK, } \\
& \text { 2005, p. 111). }
\end{aligned}
$$

Ao apreciar a estrutura histórica vivenciada no Brasil do início dos anos noventas, Caetano percebe a persistência de elementos que permearam a vida social brasileira no período anterior. A manutenção da criminalidade nos grandes complexos urbanos nacionais, fundada no estabelecimento e fortalecimento do setor narcotraficante, as mazelas econômicas enfrentadas pelo país desde a eclosão das complicações inflacionárias de meados da década de 1980, e intensificadas na nova década, faziam com que o artista estivesse convicto de que a pretensa nova ordem mundial não era observada na 
267 | InterAção

realidade doméstica. Neste sentido, atesta na canção Fora da Ordem o seguinte panorama:

Vapor Barato, um mero serviçal do narcotráfico,/ Foi encontrado na ruína de uma escola em construção/ Aqui tudo parece que é ainda construção e já é ruína/ Tudo é menino e menina no olho da rua/ O asfalto, a ponte, o viaduto ganindo pra lua/ Nada continua (VELOSO, 1991).

Analisando este trecho, a frase "aqui tudo parece construção e já é ruína" sobressai-se como instigante para a compreensão do argumento de Caetano. Define certa desilusão com o Brasil, enquanto projeto nacional, escondendo por detrás de si uma revigoradora esperança de que a construção seja retomada, pois ainda há a necessidade de se construir. $\mathrm{O}$ dilema proposto entre o ceticismo quanto às possibilidades de efetivação do projeto Brasil e sua antítese, a confiança na possibilidade de êxito em tal empreendimento, surge como elemento motriz dos exames efetuados pelo artista ao mencionar que:

Uma das vantagens da nossa abominável situação é podermos pensar que tudo ainda está por fazer. 
Dito assim, isso parece um lugarcomum estéril. E, pior, pode trazer a seguinte pergunta como complemento: e se justamente o Brasil tivesse sido uma grande oportunidade que se perdeu irremediavelmente, deixando-nos apenas com a degradação social que é demasiadamente complexa para servir de papel em branco ou ponto de partida, ou seja, se estivermos diante da mera entropia, e não do caos inicial de onde se pode extrair uma ordem bela (VELOSO, 2005, p. 61-62)?

O ímpeto de Caetano foca-se na desconstrução das convenções teórico-científicas surgidas com o fim da Guerra Fria no seio da potência hegemônica, e suas pretensões de universalização. Mais especificamente, visa elucidar a situação dissonante do Brasil neste cenário, para além dos anseios hegemônicos, evidenciando as debilidades estruturais historicamente presentes na realidade nacional, persistentes na nova conjuntura mundial.

[...] o que aparece tematizado na canção não é exatamente a exclusão que os países ricos, alinhados a essa "nova ordem", impõem àqueles considerados economicamente pobres, como o Brasil, mas a exclusão congênita, intestina, que se autoalimenta da própria miséria do país: 
269 | InterAção

assassinatos, tráfico de drogas, crianças morando nas calçadas e brincando com armas, montanhas de lixo nas ruas, esgotos a céu aberto; um estado precário de eterna construção que não chega a se completar, transformando-se logo em ruína (WISNIK, 2005, p. 20).

De tal forma, era inconcebível ao artista a inclusão do Brasil nessa ordem benéfica e progressista, que levaria toda a humanidade - de acordo com as capacidades de cada parcela - rumo à liberalização (FUKUYAMA, 2007). O Brasil era, nesta acepção, um ator marginal, envolvido nessa estrutura histórica, todavia, destoando de suas linhas-mestras.

Terrível e luminoso, o Brasil não está nem incluído na "nova ordem", podendo gozar de seus privilégios, nem comprometido ideologicamente com suas causas. E é justamente tal ambiguidade que vem determinar a dificuldade de se encontrar um lugar certo para o Brasil nessa "nova ordem" (WISNIK, 2005, p. 21).

Conseguintemente, torna-se possível aproximarmos as inquietações e inconformismos de Caetano Veloso, presentes na canção Fora da Ordem, com o empreendimento contestatório da teoria crítica coxiana. As forças potenciais, os relacionamentos entre os diversos 
atores relevantes na análise das relações internacionais do novo período, delimitando a estrutura mundial de poder, eram todos fatores amplamente dispersivos, desbordandose das lógicas de "fechamento" em categorias rígidas. É neste sentido que Caetano provoca tais abordagens, mencionando a dinâmica dos relacionamentos sociais contemporâneos, e a dificuldade de enquadrá-los em categorias rígidas.

Nietzsche (2001) havia analisado as disputas relativas à ciência e à cultura, com as pretensões universalistas e racionalistas da ciência que, por vezes, intentavam captar a essência do mais íntimo do ser humano por meio de seus métodos, logrando tão somente apresentar sua aparência e, de tal modo, empenhar-se em caracterizá-la como a essência de seu objeto de estudo.

Percebemos, assim, a relevância do papel desempenhado pela difusão da obra de Caetano Veloso ao debate do novo ordenamento mundial emergido na década de 1990. A clareza, precisão e sensibilidade com que o artista logra apresentar sua inquietação com as abordagens hegemônicas do novo período das relações internacionais apenas endossam e auxiliam o 
271 | InterAção

empreendimento da teoria crítica coxiana, determinada à contestação do positivismo e do universalismo dessas abordagens.

Enquanto Fukuyama (2007) buscava elucidar a formação de um Sistema Internacional benéfico, tendente à acomodação das tensões conflituosas por sua absorção ao projeto da globalização liberal, Huntington (1997) temia o acirramento da conflituosidade causado pela necessidade de coletivização do ser humano, tendo na civilização o grupo social mais propenso a englobar os interesses expansivos das distintas agrupações humanas, mantendo sua vinculação à coletividade por meio da identificação de valores, cultural e religiosa. Por sua parte, a teoria crítica coxiana, Hobsbawm (2005 e 2007) e Caetano Veloso, questionavam aqueles modelos analíticos, por sua aproximação decisiva com a conservação dos novos arranjos de poder.

Os fenômenos que eram tidos pelas novas abordagens do centro hegemônico como balizadores das relações internacionais no novo período histórico já haviam sido considerados por outras matrizes analíticas. O que se observou, de fato, foi a manutenção das 
problemáticas que instigavam os estudos das teorias contestatórias nas décadas anteriores, contudo, favorecidas agora pelo desbordamento de tais complicações no cenário internacional. Sob tais apreciações, poderíamos considerar que a ordem mundial proposta por Fukuyama ou por Huntington seja o próprio fator que "está fora da ordem". A observação de tais eventos fez com que Nye (2009, p. 307) lança-se o veredicto: "Com o fim da Guerra Fria, houve uma boa quantidade de conversações sobre as perspectivas de 'uma nova ordem mundial'. Como descobrimos depois, estávamos longe de entender com clareza seu significado".

\section{A FUNÇÃO DAS MÍDIAS NA DIFUSÃO DO PROJETO HEGEMÔNICO}

Todavia, o discurso do presidente estadunidense George Herbert Walker Bush (1989-1993) - endossado pela teoria do "fim da história" - de que emergia uma nova ordem mundial, difundia-se amplamente pelos meios de comunicação, que, como apontado por Gramsci e Cox, 
273 | InterAção

reservam papel de suma importância ao projeto hegemônico. Tal discurso fora avalizado pelo êxito da segurança coletiva no episódio da Guerra do Golfo, no afã de demonstrar que os desafios à segurança internacional também seriam solucionados de modo conjunto, fomentando o estabelecimento e manutenção da ordem hegemônica estadunidense.

A invasão do Kuwait pelo Iraque em 1990 foi a primeira crise pós-Guerra Fria. Uma vez que a União Soviética e a China não exerceram seus vetos, a segurança coletiva da ONU foi usada pela primeira vez em quarenta anos. Houve três razões para essa notável ressurreição. Primeiro, o Iraque cometeu uma agressão extraordinariamente bem definida, muito semelhante à da década de 1930, que lembrou aos líderes o fracasso da segurança coletiva. A segunda razão foi o sentimento de que, se a segurança coletiva da ONU falhasse nesse caso tão bem definido, então ela não seria um princípio para a ordem num mundo pós-Guerra Fria. Terceiro, os pequenos estados das Nações Unidas apoiavam a ação porque a maioria deles era frágil e tinha fronteiras pós-coloniais questionáveis (NYE, 2009, p. 216).

A receptividade que tal discurso teve nos países subordinados, especialmente no Brasil sob o governo de 
Fernando Collor de Mello (1990-1992), entusiasta do rompimento com o legado do período anterior, foi percebida argutamente por Caetano Veloso na canção Santa Clara, padroeira da televisão ${ }^{3}$ (VELOSO, 1991), oferecendo outro elemento de aproximação de sua contribuição artística com a teoria crítica coxiana.

A cobertura midiática de eventos internacionais, notadamente após a participação norte-americana na Guerra do Vietnã (1965-1973), o crescente interesse pelos assuntos internacionais e a difusão massiva das mídias, especialmente da televisão, tornaram o papel da mídia um elemento crucial para a análise das relações internacionais contemporâneas.

O papel central da grande imprensa na política moderna é flagrante. Graças a ela, a opinião pública é mais poderosa do que em qualquer período anterior, o que explica a ascensão ininterrupta das profissões que se especializam em influenciá-la. Menos compreendido é o vínculo crucial que existe entre a política de imprensa e a ação direta, ou seja, a ação vinda de baixo e que influencia diretamente os principais tomadores de decisões,

\footnotetext{
${ }^{3}$ Segundo registros da época, um ano antes de sua morte em 1253, Santa Clara (Clara de Assis) assistiu a Celebração da Eucaristia sem precisar sair do seu leito. É por tal evento que é aclamada contemporaneamente como protetora da televisão.
} 
275 | InterAção

ignorando os níveis intermediários da representação governamental oficial. Isso é particularmente óbvio quando tais níveis intermediários não existem, isto é, nos assuntos transnacionais (HOBSBAWM, 2007, p. 108).

Neste sentido, o fim da Guerra Fria, o consenso neoliberal e os genéricos discursos da globalização, emergem como fenômenos sobremaneira relevantes para analisarmos o papel da mídia na difusão do projeto hegemônico estadunidense.

Caetano Veloso, partindo de uma observação da realidade brasileira, aponta para os desafios postos à difusão dos meios de comunicação e seus efeitos na sociedade. Primeiramente, deve-se considerar que Caetano estava presenciando o processo de democratização, iniciado com o governo de José Sarney (1985-1990), e que acabava de presenciar a primeira eleição direta para a presidência após o regime militar, realizada em 1989. Neste contexto, a liberdade de expressão afirmava-se paulatinamente na realidade brasileira, ao mesmo tempo em que recebia amplas pressões dos centros de poder mundial para a consideração de fenômenos e eventos essenciais para a humanidade no novo cenário. 
Consequentemente, Caetano alerta para uma dupla necessidade relativa ao que tange o papel das mídias nesse cenário.

[Por um lado,] Que o menino de olho esperto saiba ver tudo/ Entender certo o sinal certo se perto do encoberto/ Falar certo desse perto e do distante porto aberto [...]. [Por outro,] Que a televisão não seja o inferno, interno, ermo/ Um ver no excesso o eterno quase nada (quase nada) (VELOSO, 1991).

O sujeito "menino" utilizado por Caetano pode ser compreendido em outro contexto, ao considerarmos a estrutura histórica que envolve o momento da produção do artista. No início dos anos 1990, a democratização brasileira possibilitava a participação universal, independente de classe, etnia, gênero, religião, escolaridade e, de tal modo, atores sociais que até então eram "infantilizados" pelos processos políticos nacionais, passavam a atuar, recebendo direito de decisão no processo eleitoral. Sendo assim, a categoria "menino" pode ser expandida para todos aqueles atores marginalizados nos períodos anteriores. 
277 | InterAção

Se, de uma parte, os "meninos" deveriam ter consciência das informações que recebiam, e saberem discernir os fatos dos artifícios relativos às tendências do meio de comunicação que estes consumiam, de outra parte, Caetano alerta para a premência de que a televisão não se torne um "inferno, interno, ermo" e, principalmente, "quase nada" (VELOSO, 1991). Neste trecho, Caetano foca no papel social da mídia, que não deve ater-se ao seu ambiente interno, e sim atuar enquanto ator social com potencial de influenciar nos distintos processos humanos.

É aqui que voltamos à aproximação de Caetano Veloso com a teoria crítica de Robert Cox. Segundo Cox (1986), dentre as ideias relevantes para o estabelecimento e manutenção de uma estrutura histórica, as imagens coletivas recebem função essencial. Tais imagens coletivas referem-se ao modo como os diferentes grupos percebem a ordem social vigente, resultando em visões distintas, relativas às concepções de justiça e bem público, como exemplificado pelo autor.

As imagens coletivas possuem um caráter dual. Da coalizão entre imagens coletivas rivais é que surgem 
possibilidades de formas distintas de desenvolvimento para a estrutura histórica (COX, 1986). É dizer, podem servir tanto aos projetos alternativos quanto aos hegemônicos, residindo aqui sua importância crucial. E, no mundo do pós-Guerra Fria, haviam elementos mais eficientes para a difusão de imagens coletivas que os meios de comunicação?

\footnotetext{
Estamos todos familiarizados com o chamado efeito $\mathrm{CNN}$ : o sentimento politicamente poderoso, mas totalmente desestruturado, de que "algo precisa ser feito" em função das imagens televisivas de terríveis atrocidades cometidas [...], cuja força é tão grande que gera em resposta ações governamentais mais ou menos improvisadas (HOBSBAWM, 2007, p. 108-109).
}

Com a universalização do projeto hegemônico estadunidense, a divulgação dos ideários da globalização liberal, da democracia liberal e dos direitos humanos passaram a pautar parcela considerável das informações transmitidas. Por outro lado, com a imersão definitiva da sociedade brasileira na indústria cultural (ADORNO, 2009), após a reabertura democrática, os meios de comunicação, definitivamente a televisão, depararam-se com a linha divisória da informação e do entretenimento, 
279 | InterAção

havendo que adequarem-se às necessidades do mercado, não obstante, correndo o risco de frivolidade. Por conseguinte, Caetano sugere que:

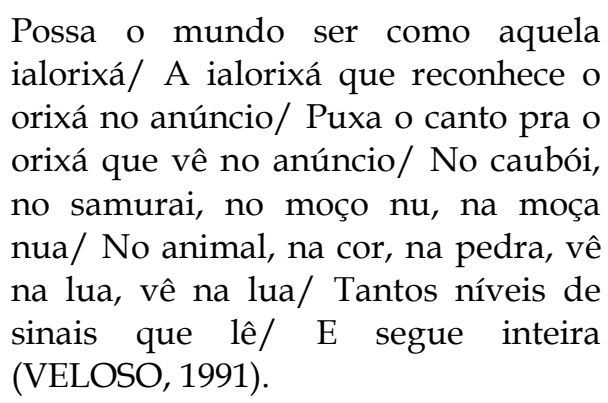

O foco do aporte de Caetano reside na resistência da consciência individual e coletiva frente às investidas da publicidade, em seus anseios de fetichizar elementos da realidade social. $\mathrm{O}$ ator social deve discernir entre sua realidade efetiva, a estrutura histórica em que está inserido, e as imagens transmitidas pela mídia, pertinentes ao escopo comercialista que ganhou novo fôlego com sua compactuação com os meios de comunicação de massa.

Quando o ator social compreende esta lógica, pode então utilizar-se dos meios de comunicação como ferramenta para a divulgação de seus projetos. O potencial de penetração da televisão na vida social a transforma em um instrumento eficiente aos movimentos contestatórios, 
restando a estes a adaptação às oportunidades postas. É, então, necessário: "Saber calar, saber conduzir a oração/ Possa o vídeo ser a cobra de outro éden/ Porque a queda é uma conquista/ E as miríades de imagens suicídio/ Possa o vídeo ser o lago onde Narciso/ Seja um deus que saberá também/ Ressuscitar" (VELOSO, 1991).

Neste âmbito, Eric Hobsbawm registra o papel da mídia como elemento fomentador da agitação social, contudo, a disposição das massas em manifestar-se seguia sendo o fator essencial para que tais eventos ocorressem (HOBSBAWM, 2005).

A opção de Caetano Veloso por tratar da televisão em sua contribuição para a análise das implicações políticas dos meios de comunicação não reside apenas em sua declarada paixão por esta forma de mídia específica (VELOSO, 1997) - explicitada no trecho “Que a televisão não seja sempre vista/ Como a montra condenada, a fenestra sinistra/ Mas tomada pelo que ela é/ De poesia" (VELOSO, 1991) -, senão que na potencialidade inerente a um dos aparelhos mais influentes nas relações sociais da segunda metade do século XX. 
281 | InterAção

[...] embora um aparelho de TV continuasse sendo muito mais caro e fisicamente desajeitado que um de rádio, logo se tornou quase universal e constantemente acessível mesmo para os pobres de alguns países atrasados, sempre que existia uma infra-estrutura urbana. Na década de 1980 , cerca de $80 \%$ de um país como o Brasil tinha acesso à televisão. Isso é mais surpreendente que o fato de nos EUA o novo veículo ter substituído tanto o rádio quanto o cinema como a forma padrão de diversão popular na década de 1950, e na próspera GrãBretanha na década de 1960. Sua demanda de massa era esmagadora (HOBSBAWM, 2005, p. 484).

Outra implicação da atuação da mídia nos processos políticos é apresentada e debatida por Eric Hobsbawm, evidenciando a função política dos meios de comunicação sob o marco dos regimes democráticos, aportando elementos substanciais para a análise de um dos pilares do projeto hegemônico estadunidense, qual seja, a universalização da democracia liberal. Sob este âmbito, o historiador inglês evidencia que:

[...] a tendência cada vez mais sistêmica de governos contornarem o processo eleitoral ampliou a função política dos meios de comunicação, que agora chegavam a todas as casas, proporcionando de longe o mais 
poderoso meio de comunicação da esfera pública para os homens, mulheres e crianças privados. Sua capacidade de descobrir e publicar o que as autoridades desejavam manter na sombra, e de dar expressão a sentimentos públicos que não eram, nem podiam ser, articulados pelos mecanismos formais da democracia, transformavam esses meios de comunicação nos grandes atores no cenário público. Os políticos os usavam e temiam (HOBSBAWM, 2005, p. 559).

A necessidade que os governantes passaram a ter de manterem vínculos com a mídia, cautelosamente, imbuiu-a de um poder singular, que se acrescia àquele advindo da própria potencialidade intrínseca aos meios de comunicação. Ademais, como analisa Hobsbawm, com todo o progresso da tecnologia de informação, os meios de comunicação sobressaíram, e muito, aos possíveis constrangimentos do aparato repressor estatal no pósGuerra Fria.

O progresso técnico tornava-os cada vez mais difíceis de controlar, mesmo em países altamente autoritários. $\mathrm{O}$ declínio do poder do Estado deixavaos mais difíceis de monopolizar nos Estados não autoritários. Quando o século acabava, tornou-se evidente que os meios de comunicação eram um componente mais importante do 
283 | InterAção

processo político que os partidos e sistemas eleitorais, e provavelmente assim continuariam - a menos que os políticos dessem uma forte guinada para longe da democracia (HOBSBAWM, 2005, p. 559).

Conseguintemente, emerge a necessidade de debatermos outra categoria central do ordenamento hegemônico pós-Guerra Fria, e que fora perspicazmente captada e analisada por Caetano Veloso, a democracia.

\section{CARÁTER MULTIFACETADO DA DISSEMINAÇÃO DA DEMOCRACIA: PERSPECTIVAS DOMÉSTICAS E INTERNACIONAIS}

Como abordado anteriormente, o tema da democracia esteve presente na obra de Caetano marcadamente durante a década de 1980, quando o Brasil finalizava seu processo de transição democrática, com o fim do regime militar, as eleições indiretas no Colégio Eleitoral em 1984, o governo de José Sarney, a promulgação da Constituição de 1988 e as eleições nacionais diretas de 1989. Entretanto, o êxito na transição pacífica para a democracia contrapunha-se à manutenção 
das assimetrias que corroíam a sociedade brasileira. Este fenômeno recebeu consideração especial por Caetano em seus escritos nas décadas de 1990 e 2000, enquanto em sua obra cancional tal preocupação expressar-se-á na canção $O$ herói (2006), foco desta análise. Deste modo, Caetano Veloso se destacará pela:

[...] capacidade de desafiar a sobrevivência de práticas arbitrárias e retrógadas no seio da "Nova República" [...]. Portanto, retirado o álibi da opressão política e ideológica, era necessário mostrar, naquele momento, que não tínhamos mais o direito de reproduzir visões colonizadas de nós mesmos (WISNIK, 2005, p. 114-115).

A democracia representa a faceta política do projeto hegemônico, ademais, exprime o desenvolvimento histórico desta que é uma das instituições fundamentais da sociedade estadunidense. Portanto, o desfecho da bipolaridade trouxe consigo a intensificação da crença na democracia por parte dos governantes norte-americanos. “O sucessor democrata de Bush, o presidente Bill Clinton, definiu os objetivos americanos em termos muito parecidos, preceituando sobre o tema de 'expandir a democracia'” (KISSINGER, 1999, p. 881). 
285 | InterAção

Destarte, faz-se necessário expormos os riscos advindos da difusão da ideologia da democracia liberal, enquanto integrante do projeto universalizante da potência hegemônica, aos países receptores das mudanças preconizadas pelos centros de poder mundial. Primordialmente, há de se considerar os desafios advindos dos demais atores - internos e internacionais aos Estados-nações, impondo-lhes constrangimentos que delimitam a eficácia das estruturas políticas.

Do lado prático, os governos dos Estados-nações, ou dos Estados territoriais modernos - quaisquer governos -, apoiam-se em três presunções: primeiro, que eles têm mais poder do que qualquer outra unidade que opere em seus territórios; segundo, que os habitantes dos seus territórios aceitam mais ou menos de bom grado sua autoridade; e terceiro, que eles podem proporcionar aos habitantes serviços que de outra maneira não poderiam ser prestados com efetividade, como é o caso da manutenção da lei e da ordem. Nos últimos trinta ou quarenta anos, essas presunções têm perdido cada vez mais a validade (HOBSBAWM, 2007, p. 104).

Tais implicações relacionam-se à capacidade do Estado para manter o monopólio do uso da força dentro 
de seu território, com instituições que lhe permitam a direção da sociedade sobre as bases da lei e da ordem. Deste modo, ao apreciarmos esses fenômenos, devemos ter em mente que ao referirmo-nos às capacidades do Estado, estamos considerando “[...] a extensão das intervenções dos agentes estatais em recursos não estatais, as atividades e as conexões interpessoais alteram as distribuições existentes desses recursos, atividades e conexões interpessoais, bem como as relações entre as distribuições" (TILLY, 2013, p. 174).

Tilly (2013) empenha-se em descrever e explicar as variações e alterações que ocorrem na extensão com que o Estado comporta-se ao deparar-se com as demandas expressas pelos seus cidadãos. Por conseguinte, no afã de esclarecer tais pretensões, o autor divide sua investigação em quatro partes, que são amplamente úteis para nossa compreensão e análise do que seja a democracia, contrapondo esta concepção com a fornecida pela ideologia hegemônica da democracia liberal. As quatro partes trabalhadas por Charles Tilly são:

[...] o quão amplas são as demandas expressas pelos cidadãos, como diferentes grupos de cidadãos 
287 | InterAção

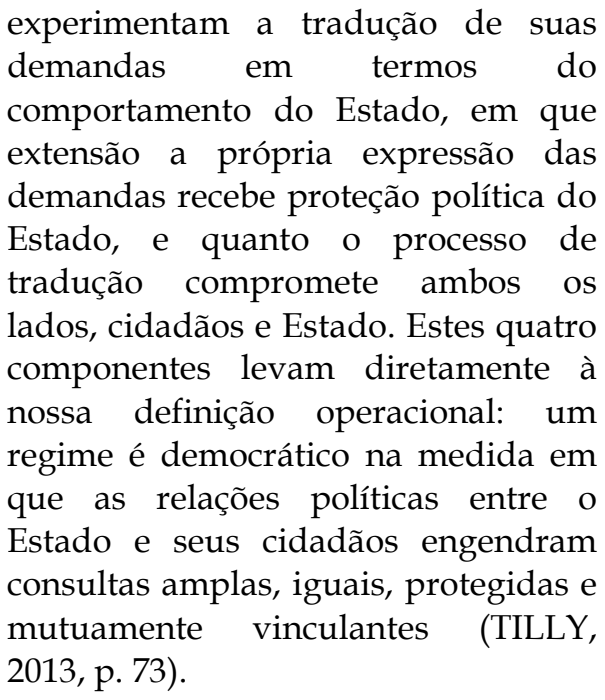

Paulatinamente, definimos as linhas analíticas que permeiam um conceito de democracia na contemporaneidade. Assim, podemos apontar que "um regime democrático inclui eleições que são limpas e institucionalizadas, assim como uma aposta institucionalizada, inclusiva e universalista" (O'DONNELL, 2013, p. 29). Deste modo, é na aposta institucionalizada democrática que reside um dos fatores imprescindíveis às pretensões de um projeto democrático. Enquanto os atores políticos aceitarem que esta é a forma mais eficiente, ou menos custosa, de atingirem seus objetivos, aceitarão participarem da competição eleitoral. Quando não o percebem de tal modo, valem-se de outros 
meios, normalmente coercitivos e violentos, a fim de substituírem a ordem vigente.

Proeminente figura da política externa norteamericana, Henry Kissinger alerta, do mesmo modo, para a observação das assimetrias existentes entre as sociedades dos países dominados e a estadunidense, as capacidades materiais dos Estados, bem como a conformação das oposições e sua atuação no jogo políticoinstitucional. Por conseguinte, aponta que:

Refrear o poder do governo central tem sido uma das principais preocupações dos teoristas políticos ocidentais, enquanto, na maioria das outras sociedades, a teoria política tem tentado sustentar a autoridade do estado. [...] $\mathrm{Na}$ maioria das outras partes do mundo, o estado tem precedido a nação; ele foi, e frequentemente continua sendo, o elemento principal na sua formação. Os partidos políticos, onde existem, refletem identidades fixas e geralmente locais; minorias e maiorias tendem a ser permanentes. Em tais sociedades, o processo político trata de dominação, e não de alternância nos cargos, que ocorre, quando ocorre, através de golpes, em vez de procedimentos constitucionais. $\mathrm{O}$ conceito da oposição leal - essência da democracia moderna - raramente se firma. O mais normal é a oposição ser 
289 | InterAção

vista como ameaça à coesão nacional, igualada à traição, e impiedosamente reprimida (KISSINGER, 1999, p. 889).

Logo, ao efetivarem a aposta democrática, os atores políticos pressupõem, e necessitam de, algumas liberdades e direitos que lhes sejam garantidos a fim de apresentarem, discutirem e efetivarem seus projetos para a sociedade. Desse modo:

\begin{abstract}
A cidadania política consiste da atribuição universal (embora territorialmente delimitada) dos direitos e liberdades vinculados a uma aposta democrática inclusiva, ou seja, tanto de algumas liberdades circundantes quanto dos direitos à participação em eleições limpas e institucionalizadas, incluindo votar e ser eleito(a) (O'DONNELL, 2013, p. 34).
\end{abstract}

Consequentemente, ao analisar os processos de democratização e desdemocratização, Charles Tilly apresenta três caminhos que os Estados podem percorrer ao buscarem incrementar sua capacidade e avançarem na democratização. Primeiro, aparecem os Estados fortes, nos quais a capacidade do Estado aumenta muito antes da evolução da democratização. Segundo, apresentam-se os Estados médios, onde ocorre a concatenação do aumento 
na capacidade do Estado com o processo de democratização, e, portanto, qualquer alteração no movimento da capacidade do Estado tem efeito similar na democratização. E terceiro, o caminho dos Estados fracos, possuidores de poucos recursos, refletindo em baixa capacidade do Estado, que, por conseguinte, dificulta o processo de democratização, especialmente na contenção de agentes complicadores, tornando a desdemocratização muito mais frequente - e fácil de ocorrer - que nos outros dois caminhos (TILLY, 2013).

Não obstante, a retórica universalizante da democracia liberal ignora essas nuances da construção democrática, referentes às assimetrias dos Estados quanto às suas capacidades materiais essenciais para $\mathrm{O}$ estabelecimento e a manutenção do regime democrático.

Ao considerar a realidade brasileira, Caetano Veloso fornece uma contribuição reveladora da manutenção das assimetrias sócio-econômicas, mesmo após a democratização, fazendo com que sejam necessários esforços sobremaneira custosos para a manutenção do regime democrático. Numa apresentação pessoal do "herói" da canção, este relata sua trajetória de 
291 | InterAção

vida do seguinte modo: "Nasci num lugar que virou favela/ cresci num lugar que já era/ mas cresci a vera/ fiquei gigante, valente, inteligente/ por um triz não sou bandido/ sempre quis tudo o que/ desmente esse país/ encardido" (VELOSO, 2006).

Neste trecho, o artista explicita que o sujeito da canção teve sua trajetória pessoal permeada pela desigualdade social, que lhe constrangeu as opções e escolhas na construção de sua identidade e de sua carreira. Ao rejeitar tudo o que considera imundo, e que está impregnado em sua sociedade, o "herói" constata a existência de tratamentos diferenciados por parte do Estado. Esse fenômeno é profundamente corrosivo para o regime democrático, por ser fundamental a isonomia e a igualdade de tratamento de todos os cidadãos pelos agentes estatais. "Na democracia, as instituições do estado têm o dever (correlativo aos direitos da cidadania política e civil) de tratar a todos com a equidade, consideração e respeito devidos a um agente" (O'DONNELL, 2013, p. 55). Essas disparidades entre os indivíduos são fatores que minam o processo de democratização, restringindo-lhe as possibilidades de êxito. 


\title{
292 InterAção
}

\begin{abstract}
A desigualdade social impede a democratização e mina a democracia sob duas condições: primeiro, a cristalização de diferenças contínuas (tais como aquelas que distinguem você de seu vizinho) e diferenças categóricas cotidianas em virtude de fatores como raça, gênero, classe, etnia, religião e outros tipos de agrupamentos similares; segundo, a tradução direta dessas diferenças categóricas em diferença nos processos políticos públicos (TILLY, 2013, p. 123).
\end{abstract}

As diferenças categóricas são aprofundadas por Caetano na canção, quando o "herói" define seu projeto individual, expressando as consequências que este teria para a coletividade em que ele está inserido. Neste sentido, ele menciona: "descobri cedo que o caminho/ não era subir num pódio mundial/ e virar um rico olímpico e sozinho/ mas fomentar aqui o ódio racial/ a separação nítida entre as raças" (VELOSO, 2006).

O argumento apresentado por Caetano é poderosamente fomentador de reflexões acerca das implicações do reconhecimento/não reconhecimento e da igualdade/subordinação para os processos políticos relativos ao regime democrático. Sob tal âmbito, Nancy Fraser ofereceu uma análise reveladora dos efeitos de se 
293 | InterAção

considerar o reconhecimento - e, portanto, a igualdade como uma questão de status.

\begin{abstract}
Entender o reconhecimento como uma questão de status significa examinar os padrões institucionalizados de valoração cultural em função de seus efeitos sobre a posição relativa dos atores sociais. Se e quando tais padrões constituem os atores como parceiros, capazes de participar como iguais, com os outros membros, na vida social, aí nós podemos falar de reconhecimento recíproco e igualdade de status. Quando, ao contrário, os padrões institucionalizados de valoração cultural constituem alguns atores como inferiores, excluídos, completamente "os outros" ou simplesmente invisíveis, ou seja, como menos do que parceiros integrais na interação social, então nós podemos falar de não reconhecimento e subordinação de status (FRASER, 2007, p. 108).
\end{abstract}

Portanto, o "herói" empreende uma busca por reconhecimento, em novos padrões de identidade, que rompam com os vigentes em sua realidade social. Neste sentido ele diz que: "já fui mulato, eu sou uma legião de ex mulatos/ quero ser negro 100\%, americano,/ sul-africano, tudo menos o santo/ que a brisa do Brasil briga e balança" (VELOSO, 2006). Todavia, seu 


\title{
294 InterAção
}

empreendimento no intento de ser reconhecido pela coletividade está fundado no reconhecimento da diferença, e não na igualdade. Ele quer ser reconhecido como um indivíduo distinto do agrupamento criado pela sociedade, que o mesmo define como "santo". Então, depara-se com as dificuldades advindas da reivindicação pelo reconhecimento da diferença.

\begin{abstract}
Normas de justiça são pensadas como universalmente vinculatórias; elas sustentam-se independentemente do compromisso dos atores com valores específicos. Reivindicações pelo reconhecimento da diferença, ao contrário, são mais restritas. Por envolverem avaliações qualitativas acerca do valor relativo de práticas culturais, características e identidades variadas, elas dependem de horizontes de valor historicamente específicos que não podem ser universalizados (FRASER, 2007, p. 104).
\end{abstract}

Além disso, regressando à distribuição dos recursos materiais, os indivíduos marginalizados devem ser integrados na sociedade democrática enquanto cidadãos, de modo que a redistribuição dos recursos materiais possibilite sua independência e o porte de voz participativa. Esta seria uma condição objetiva da 
295 | InterAção

paridade participativa. Por outro lado, há uma segunda condição, denominada de condição intersubjetiva, requerendo dos padrões institucionalizados de valoração cultural a expressão de igualdade no respeito a todos os seus participantes, assegurando igualdade de oportunidade para alcançar a estima social. Assim, “são excluídos os padrões institucionalizados de valores que negam a algumas pessoas a condição de parceiros integrais [...], seja sobrecarregando-os com uma excessiva atribuição de 'diferença', seja falhando em reconhecer o que lhes é distintivo" (FRASER, 2007, p. 119-120).

Deparando-se com a dualidade do padrão de socialização que havia recebido ao longo de sua vida, fundado em preceitos universais dentro da sociedade em que participa, e do novo padrão que buscava implantar, o "herói" percebe o choque de valores, crenças e ideais inerentes ao seu intento de universalização do reconhecimento através da diferença. Neste momento, ele realiza a auto-avaliação de seu projeto, concluindo que: "no entanto, durante a dança/ depois do fim do medo e da esperança/ depois de arrebanhar o marginal, a puta/ o evangélico e o policial/ vi que o meu desenho de mim/ é 


\section{InterAção}

tal e qual/ o personagem pra quem eu cria que sempre/ olharia/ com desdém total" (VELOSO, 2006).

Essa alteração na percepção da realidade, ocorrida com o sujeito, bem como de sua concepção do projeto que havia perpetrado, vincula-se com um fato inerente à própria condição humana, podendo ser potencializada ou mitigada pela ação da estrutura histórica.

Esse fato é consequência de restrições
institucionais e econômicas, mas
também da diversidade social que
advêm da agência humana e,
portanto, das diversas perspectivas,
estilos de vida, ideologias e interesses
que os agentes representam, seja
(estaticamente) num momento
determinado, seja quando essas
características se desenvolvem e se
modificam (dinamicamente) no
transcorrer do tempo (O'DONNELL,
2013, p. 83).

É possível notar, até aqui, que o "herói" da canção de Caetano Veloso consiste em um líder de determinado setor da sociedade, que perpetrou a implantação de um projeto de sociedade, flagrantemente contrário àquele vigente. Este projeto é sintetizado na declaração do "herói" de que: "É como em plena glória espiritual/ que digo:/ eu sou o homem cordial/ que vim para instaurar a 
297 | InterAção

democracia racial/ eu sou o homem cordial/ que vim para afirmar a democracia racial" (VELOSO, 2006).

Assim, Caetano analisa o processo de democratização do Brasil concomitantemente com a afirmação das disparidades sociais, especificamente as relativas à etnia, comparando o processo vivenciado no âmbito brasileiro com o estadunidense, logrando atingir as seguintes conclusões:

Para mim é óbvio que os Estados Unidos, ao superar (sic.) a situação de racismo institucionalizado, em poucas décadas tinham um negro como chefe do Estado-Maior das suas Forças Armadas, três prefeitos negros nas suas três maiores cidades, muitas aeromoças negras em seus aviões e crianças negras em seus anúncios de televisão - enquanto nós não temos generais negros sequer e o nosso único governador negro, o do Espírito Santo, teve sua filha barrada na entrada "social" de um prédio na capital do seu estado; mas isso não nos deve levar a pensar que institucionalizar o racismo teria sido necessariamente melhor para nós: o que faz a enorme diferença entre o nazismo e outras formas de perseguição assassina de raças e minorias é o fato de, no caso do nazismo, esses massacres serem oficiais (VELOSO, 2005, p. 45). 


\section{InterAção}

No entanto, quais são as implicações deste projeto para o processo de democratização? Retornando aos apontamentos de Charles Tilly, existem três categorias centrais de mudanças para os processos de democratização e de desdemocratização:

1) Aumento ou diminuição da integração entre redes de confiança interpessoais (por exemplo, parentesco, pertencimento religioso e relações de mercado) e processos políticos públicos. 2) Aumento ou diminuição no insulamento dos processos políticos públicos em relação às principais desigualdades categóricas (por exemplo, as de gênero, raça, etnia, religião, classe, castas) em torno das quais os cidadãos organizam suas vidas cotidianas. 3) Aumento ou diminuição na autonomia em relação aos processo políticos públicos por parte dos principais centros de poder (especialmente aqueles que se valem de meios coercitivos significativos), tais como as milícias, as redes de clientelismo, o exército, e as instituições religiosas (TILLY, 2013, p. 37).

Todas essas categorias de mudanças são

potencializadas ou amenizadas de acordo com as capacidades do Estado. Referem-se à atuação de atores não-governamentais, que, desde a década de 1970, 
299 | InterAção

passaram a influenciar diretamente os processos políticos, econômicos e sociais. Esta afirmação é sobremaneira verificável no âmbito dos "Estados fracos" e seus esforços para a democratização.

As implicações são óbvias, ao menos em teoria: um Estado fraco enfrenta importantes obstáculos à democratização até encontrar um ponto limítrofe. Esses obstáculos existem porque um Estado fraco falha em suprimir ou subordinar os centros de poder autônomos, permitindo aos cidadãos insular suas redes de confiança do processo político público e tolera ou mesmo encoraja a inserção de desigualdades categóricas em seus processos políticos públicos. Quando comparados com os estados fortes e médios, os estados fracos enfrentam uma maior proporção de conflitos, geralmente violentos, nos quais o Estado se vê envolvido de forma apenas periférica. [...] eles também são o maior palco da maior parte das guerras civis que ocorreram no mundo (TILLY, 2013, p. 177).

$\mathrm{Na}$ América Latina, os efeitos do projeto hegemônico na década de 1990 revelaram distintas e inovadoras perspectivas e desafios à evolução da democratização. Concatenando elementos trabalhados por Caetano Veloso na canção Fora da Ordem (VELOSO, 1991) 
com os aportes específicos da canção O Herói (VELOSO, 2006), o artista registra a perpetuação de algumas problemáticas relativas às assimetrias sociais, que dificultam o fortalecimento dos direitos políticos dos cidadãos afetados por esta lógica permanente. Nestes termos:

\begin{abstract}
Em contraste com os países pioneiros, na maior parte da América Latina (e, em termos de população, para a grande maioria da população desta região), os direitos políticos foram obtidos, ou têm sido recuperados recentemente, antes de completar-se uma generalização dos direitos civis. Por sua vez, dependendo da trajetória seguida por cada país, alguns direitos sociais foram outorgados antes ou depois dos direitos políticos, mas em todos os casos esses direitos foram limitados e ultimamente têm sofrido, em muitos países, retrocessos significativos (O'DONNELL, 2013, p. 70).
\end{abstract}

Cabe ainda ressaltar outro fator indicador dos limites do projeto hegemônico de disseminação da ideologia democrática liberal. Ao defrontarem-se com os principais dilemas do pós-Guerra Fria, as potências mundiais utilizam-se de foros e organizações democráticas de modo seletivo, sendo que algumas das 
301 | InterAção

principais problemáticas para as sociedades são debatidas e suas resoluções definidas por mecanismos frequentemente não democráticos. De tal modo:

Além de ter possibilidades muito baixas de êxito, o esforço de disseminar a democracia ocidental padronizada sofre também de um paradoxo fundamental. Em grande medida, ela é concebida como solução para os perigosos problemas transnacionais dos nossos dias. Uma parcela crescente da vida humana ocorre atualmente fora do âmbito de influência dos eleitores - em entidades transnacionais públicas e privadas que não têm eleitorados, ou pelo menos eleitorados democráticos. Uma democracia eleitoral não pode funcionar efetivamente fora de unidades políticas como os Estados nacionais. Os países poderosos estão, portanto, tratando de disseminar um sistema que eles próprios consideram inadequado para enfrentar os desafios da nossa época (HOBSBAWM, 2007, p. 119).

É nesse linear que emergem as principais críticas das demais nações à atuação das potências mundiais nas instituições internacionais. O ex-chanceler brasileiro Celso Amorim (1993-1994/2003-2010) reforça a percepção de que as potências mundiais não podem mais negar o surgimento de novos centros de poder, assegurando sua 
participação nos debates das problemáticas mundiais. “O realinhamento de forças no sistema internacional está construindo o caminho para uma ordem mais multipolar" (AMORIM, 2010, p. 215, tradução nossa). Entretanto, do mesmo modo como observado por Eric Hobsbawm, Celso Amorim constata que:

Esta tendência para a multipolaridade
não foi seguida por uma
democratização das instituições
multilaterais, que sofrem de
obsolescência progressiva. A
governança global deu-se com pouca
legitimidade, transparência e
efetividade, entre outras razões,
porque os países em desenvolvimento
continuam sub-representados
(AMORIM, 2010, p. 216, tradução
nossa).

Entrementes, considerando-se a anarquia inerente ao espaço internacional, as organizações internacionais tornam-se relevantes atores do jogo político mundial, pois os atores estatais reconhecem sua utilidade prática aos seus anseios e à estabilização das relações internacionais. Assim, as organizações internacionais "são uma parte importante da realidade política, porque influenciam a maneira como os estados se comportam. Os estados têm 
303 | InterAção

interesse na legislação internacional por duas razões:

previsibilidade e legitimidade" (NYE, 2009, p. 211).

A previsibilidade é necessária para que as transações prosperem e para o controle ordenado dos conflitos que inevitavelmente se as acompanham. [...] A legitimidade é a segunda razão pela qual os governos têm interesse na legislação internacional. A política não é meramente uma luta pelo poder material, mas também uma disputa pela legitimidade. Poder e legitimidade não são antiéticos, mas complementares. [...] É um fato político que a crença no certo e no errado ajuda a induzir as pessoas a agir, e portanto a legitimidade é uma fonte de poder. Se os atos de um estado são percebidos como ilegítimos, os custos de uma política serão altos. Os estados apelam à legislação e à organização internacional para legitimar suas próprias políticas e deslegitimar a dos outros, e isso geralmente dá forma a suas táticas e seus resultados. E a legitimidade aumenta o poder brando de um estado (NYE, 2009, p. 212).

Todavia, podemos acrescentar às considerações de Joseph Nye Jr. uma outra categoria analítica acerca da utilização das instituições internacionais pelos Estados. Refere-se ao caso da contestação e proposição de novos modos de tratamento das questões internacionais, 
304 | InterAção

fundadas no multilateralismo, sendo empreendidas pelas potências emergentes e, em certos casos, pelas potências mundiais quando afetadas pelos desígnios da potência hegemônica. Neste sentido, ressalta-se a atuação internacional do Brasil sob o marco do multilateralismo recíproco, participando das discussões dos principais problemas postos à ordem mundial após a Guerra Fria.

No concernente aos dilemas de segurança consolidados no novo cenário internacional, a diplomacia brasileira alterou seu modus operandi, paulatinamente inserindo-se nos debates travados nos fóruns internacionais desse âmbito, fundamentalmente no Conselho de Segurança das Nações Unidas. “O processo gradual mencionado [...] permitiu uma nova e notável ferramenta na política externa brasileira: o movimento de uma aproximação reativa para uma mais assertiva com relação às questões de segurança" (VIANA; VILLA, 2010, p. 91, tradução nossa).

Regressando à análise interna da canção O Herói, considerando as implicações negativas de seu projeto, após a sua implementação, o "herói" analisa-o sob perspectiva histórica, concluindo que a atual situação que 
305 | InterAção

ele vivencia é seu dilema moral, indagando-se acerca dos benefícios que seu projeto efetivamente trouxe. Isto é observado em sua afirmação final: "eu sou o herói/ só deus e eu sabemos como dói" (VELOSO, 2006). Deste modo, podemos lançar apontamentos sobre a eficácia da disseminação da democracia, por um lado para o projeto hegemônico, e por outro lado para as estruturas internas dos países afetados por tais desígnios.

Primordialmente, ao considerarmos os aportes dos autores investigados até aqui, torna-se evidente o entrelaçamento de três matérias, que, a nosso ver, devem ser tratadas de modo conjunto: a democracia, o desenvolvimento e os direitos humanos. O'Donnell (2013) referiu-se a tal entrelaçamento como decorrente da concepção do ser humano. Neste sentido, "a democracia, o desenvolvimento humano e os direitos humanos estão baseados em uma concepção similar de ser humano como um agente" (O'DONNELL, 2013, p. 16). Um dos grandes equívocos do projeto de disseminação da democracia liberal é preterir tal consideração pela crença no institucionalismo, cabendo à instauração de instituições democráticas o papel central no processo de 
306 | InterAção

democratização. Isto pode ser encontrado nas considerações de Fukuyama, quando o autor menciona que:

\begin{abstract}
Kojève proclama que chegamos ao fim da história porque a vida, neste estádio universal e homogêneo, satisfaz completamente os seus cidadãos. Por outras palavras, o mundo liberal democrático moderno está livre de contradições. [...] O cerne da questão tem a ver com princípios isto é, se as "coisas boas" da nossa sociedade são verdadeiramente boas e satisfatórias para o "homem enquanto homem" ou se existe uma forma superior de satisfação que um outro tipo de regime ou organização social poderia proporcionar (FUKUYAMA, 2007, p. 148).
\end{abstract}

As generalizações e conclusões precipitadas de Fukuyama, ao serem testadas pelos eventos do pósGuerra Fria, revelaram-se demasiado otimistas, e profundamente apressadas. Como analisado anteriormente, esses apontamentos foram efetivados de tal modo como uma contingência do momento em que surgiram. Serviram como respaldo ao projeto hegemônico estadunidense que, contudo, quando de sua implantação deparou-se com fenômenos internacionais para os quais seus desígnios não estavam adequadamente preparados. 
307 | InterAção

\section{LIMITAÇÕES À ATUAÇÃO DA POTÊNCIA HEGEMÔNICA: O SOFISMA ENTRE A PREMISSA DOS DIREITOS HUMANOS EA SEGURANÇA INTERNA}

Destarte, estamos compelidos a apresentar uma definição mínima de tais elementos, fundamentalmente dos direitos humanos, foco no presente momento. Sendo assim, diretrizes eficazes são trazidas por O'Donnell (2013), analisando tanto o desenvolvimento humano, quanto os direitos humanos.

Estas duas perspectivas têm alguns elementos cruciais em comum: ambas começam e terminam pelos seres humanos e ambas se perguntam qual pode ser, ao menos, um conjunto mínimo de condições, direitos e/ou capacidades que os permitam viver de forma apropriada a sua condição de tais. Na verdade, em suas origens, o conceito de desenvolvimento humano se concentrava no contexto social, enquanto que o de direitos humanos o fazia no sistema legal e na prevenção e reparação da violência estatal (O’DONNELL, 2013, p. 18).

Consequentemente, partindo destas considerações e, principalmente, atribuindo ao ser humano a agência no contexto analisado, adentramos no debate do 
universalismo de tais concepções, sendo este distinto em duas categorias, o universalismo limitado - restrito à lógica interna - e o universalismo irrestrito - aplicado aos ímpetos internacionais.

Note-se que esta atribuição implica designar a condição de agentes a todos os que se aplica - os (as) cidadãos (ãs). Esta condição diz respeito às relações diretamente referidas a um regime - democrático baseado em eleições limpas e institucionalizadas. Observe-se, no entanto, que esta é uma atribuição de agência feita mediante um universalismo limitado: se aplica a quase todos os adultos no território de um estado organizado segundo um regime democrático, não, por exemplo, aos estrangeiros nesse território. Este universalismo limitado se distingue do universalismo ilimitado, pois este último se predica para a garantia e expansão do desenvolvimento humano e os direitos humanos através de todo tipo de países, estados e regimes. Entretanto, o universalismo limitado dos direitos políticos tem uma vantagem distintiva sobre o segundo, a de identificar claramente aos destinatários desses direitos: esses podem ser reclamados, por meio do sistema legal, ao estado e a qualquer indivíduo que possa tê-los infringido. Trata-se, então, de direitos subjetivos (legalmente acionados) que existem pelo simples, mas fundamental, fato 
309 | InterAção

de que estes indivíduos vivem em um estado territorialmente delimitado que contém um regime democrático (O'DONNELL, 2013, p. 28).

É inerente aos preceitos de direitos humanos a sua universalização, a sua difusão por meio de normas, valores, instituições e ideias que permitam sua penetração nas distintas sociedades humanas. Portanto, "em termos da lógica de seus argumentos, [...] os patrocinadores [...] dos direitos humanos devem ser rigorosos universalistas, ao menos no que se refere à realização e defesa dos direitos, condições sociais e capacidades 'básicas' que propiciam" (O’DONNELL, 2013, p. 19).

A universalidade intrínseca ao preceito de direitos humanos tornou-se notória na retórica de atores políticos e de grupos da sociedade civil com o final da Guerra Fria. Se, por um lado, Fukuyama apresentava esse evento histórico como representando o último estágio da história, por outro lado, para a interpretação solidarista dos direitos humanos, representava a conformação das perspectivas de paz perpétua, nos moldes kantianos.

Com o final da Guerra Fria [...] a perspectiva da paz perpétua parece ter voltado a seduzir intelectuais e 
políticos, e mais uma vez o ensaio de Immanuel Kant foi resgatado para tentar compreender o mundo contemporâneo e propor medidas no sentido de construir uma paz internacional duradoura, particularmente no que diz respeito ao papel que os Direitos Humanos devem ocupar nessa nova ordem pósGuerra Fria, na qual o processo de globalização parece ter acelerado ainda mais o processo pelo qual se estabelece "uma comunidade entre todos os povos da Terra" (REIS, 2009, p. 61).

Todavia, tomando esses direitos como universais, o projeto hegemônico os adéqua a fim de legitimar tanto a dominação quanto o uso de poder coercitivo, em casos que possam ser enquadrados como flagrantes - ou com evidências mais modestas - violações dos direitos humanos, desconsidera necessidades imprescindíveis ao reconhecimento dos direitos humanos numa sociedade. Portanto, a universalização dos direitos humanos volta-se como fator potencialmente conflituoso, sobretudo por sua utilização como apologia para o uso do poderio militar dos Estados Unidos. Hobsbawm (2007), comparando a ideologia dos direitos humanos com a da abolição do tráfico de escravos pela Grã-Bretanha do século XIX, 
311 | InterAção

aponta as implicações que tal ideia pode tomar, ao observar que:

[...] a abolição do tráfico de escravos foi usada como justificativa para o poder naval britânico, assim como os direitos humanos são hoje utilizados com frequência para justificar o poder militar dos Estados Unidos. Por outro lado, os Estados Unidos, como a França e a Rússia revolucionárias, são uma grande potência que tem por base uma revolução universalista - e, por conseguinte, crê que o resto do mundo deveria seguir seu exemplo e que deve até ajudar a libertar o resto do mundo. Poucas coisas pode haver que sejam tão perigosas quanto os impérios que buscam satisfazer seus próprios fins acreditando que estão fazendo um favor à humanidade (HOBSBAWM, 2007, p. 155).

Não basta a substituição de regimes políticos para a alteração do padrão de reconhecimento dos direitos humanos. Estes se referem ao reconhecimento dos seres humanos como agentes. Sob tal âmbito, O'Donnell menciona que:

[...] esses direitos pertencem a todos os seres humanos na medida em que os reconhecemos como agentes, e que seus direitos como tais agentes na esfera política dificilmente podem ser exercidos se os indivíduos carecem das capacidades "básicas" aos que se 
312 InterAção

referem os direitos humanos (O'DONNELL, 2013, p. 77).

Ademais, não basta o reconhecimento de um Estado da necessidade de implementação de políticas públicas que visem à prevalência dos direitos humanos, do mesmo modo como da democracia. É fundamental o reconhecimento dos indivíduos enquanto agentes, dotados de direitos e liberdades, bem como a eliminação das assimetrias que impossibilitem sua agência. Neste sentido, não basta o discurso dos direitos humanos, pois este vincula-se estreitamente ao que Hobsbawm (2007) definiu como o "efeito CNN" (previamente abordado).

Não obstante, a incompatibilidade do discurso com os atos não está restrita apenas aos Estados subordinados. Neste âmbito, na canção Base de Guantánamo (VELOSO, 2009), Caetano Veloso aponta para os limites da atuação da própria potência hegemônica, ao denunciar os desrespeitos aos direitos humanos que esta realiza, em sua luta contra o terrorismo internacional.

A Base Naval da Baía de Guantánamo é utilizada pelos Estados Unidos, desde 2002, como prisão para suspeitos de terrorismo internacional. Os métodos 
313 | InterAção

utilizados, denúncias de prisões com escassas evidências, bem como das condições dos prisioneiros levaram algumas organizações a condenarem a atuação estadunidense na Base.

O foco da preocupação de Caetano Veloso referese à facilidade com que os Estados Unidos violam uma política basilar de seu projeto hegemônico, implicando indivíduos de outros Estados-nações e, principalmente, em instalações localizadas fora de seu território nacional. Por conseguinte, esta é sua denúncia:

O fato de os americanos desrespeitarem os direitos humanos/ em solo cubano/ é por demais forte/ simbolicamente/ para eu não me abalar/ A base de Guantánamo/ a base da Baía de Guantánamo/ a base de Guantánamo/ Guantánamo (VELOSO, 2009).

A canção desenvolve-se sob o ritmo marcado de uma marcha militar, com presença determinante do elemento de percussão, um bumbo que repetidamente é acionado, somado à evolução lenta da interpretação de Caetano. O teor nefasto que permeia a canção refere-se justamente à nocividade da realidade observada. Como poderiam os norte-americanos desrespeitarem os direitos 
314 | InterAção

humanos? A nação que mundialmente portava-se como baluarte da defesa de tais direitos, quando desafiada por atores não-estatais que se utilizavam de meios violentos na execução de seus projetos, acaba preterindo a realização dos direitos humanos em prol dos interesses de Estado, considerados ameaçados pela proliferação dos grupos terroristas e suas atividades em território estadunidense.

Portanto, tendo em conta a contribuição de Caetano Veloso com a canção Base de Guantánamo (VELOSO, 2009), concomitante com os aportes teóricoempíricos tratados, torna-se possível elencarmos três implicações gerais da política norte-americana de disseminação dos direitos humanos: a importância da doutrina de direitos humanos para o projeto hegemônico dos Estados Unidos no pós-Guerra Fria; os desafios enfrentados quando de sua implementação nos países subordinados; e a falácia empírica quando a potência hegemônica confrontou-se com o dilema que opunha os direitos humanos aos seus interesses de segurança.

Resta-nos analisar a segunda dessas implicações as outras duas já foram abordadas anteriormente - que, 
315 | InterAção

notoriamente, não fora apreciada de modo adequado pela potência hegemônica, constrangendo-lhe as aspirações consensuais e voltando-se complicadora para a manutenção da dominação no início do século XXI. Eric Hobsbawm constata o aumento da violência no pósGuerra Fria, ao mencionar que:

Por um lado, a escala dos sofrimentos humanos aumentou terrivelmente na década de 1990 e, por outro lado, as guerras religiosas que eram alimentadas por ideologias seculares expandiram-se com o retorno a várias formas de fundamentalismo religioso que se manifestam em cruzadas e contracruzadas (HOBSBAWM, 2007, p. 128).

Concomitantemente, Joseph Nye Jr. realiza um inventário dos conflitos armados no período do pósGuerra Fria, endossando os apontamentos de Hobsbawm quanto ao aumento da escala dos sofrimentos humanos, apresentando o seguinte panorama:

As guerras maiores tornaram-se menos prováveis depois do fim da Guerra Fria, mas os conflitos regionais e internos persistem e sempre haverá pressões para que outros estados e instituições internacionais intervenham. Dos 116 conflitos que ocorreram entre o fim da 


\section{InterAção}

Guerra Fria e o início do novo século, 89 foram puramente intraestatais (guerras civis) e outros 20 foram interestatais com intervenção estrangeira. Mais de 80 protagonistas estatais estiveram envolvidos, assim como duas organizações regionais e mais de 200 partidos não governamentais (NYE, 2009, p. 197).

Seguindo esta senda, Caetano Veloso apresenta seu inconformismo quanto ao fato do Ocidente considerar-se a vanguarda universalizante da liberdade, da democracia e dos direitos humanos, embasados na crença inequívoca de seu "dever" disseminador, por ser o berço de tais concepções. Rebatendo, neste sentido, os aportes de Huntington, Caetano elucida que:

Huntington cita também Arthur Schlesinger Jr.: "A Europa é a fonte - a fonte singular- das ideias de liberdade individual, democracia política, império da lei, direitos humanos e liberdade cultural. Essas ideias são ideias europeias, não são asiáticas, nem africanas, nem do Oriente Médio, a não ser por adoção". Mas, como disse Ernest Gellner, que tais ideias tenham surgido no Ocidente (assim como a ciência moderna) não significa que os povos brancos europeus sejam seus donos ou mesmo que estejam mais capacitados para pô-las em prática ou desenvolvê-las (VELOSO, 1997, p. 346). 
317 | InterAção

Entrementes, a escalada da violência no novo contexto internacional não advém apenas desse fenômeno de fundamentalismo religioso, o que ratificaria a análise de Huntington (1997) acerca do choque de civilizações. Refere-se, de fato, ao radicalismo tomado pelas posições político-ideológicas, que forneceu justificativas ao uso de meios violentos na consecução de tais objetivos. Consequentemente, Hobsbawm aponta que:

Existe [...] um fator mais perigoso na geração da violência sem limites. É a convicção ideológica, que desde 1914 domina tanto os conflitos internos quanto os internacionais, de que a causa que se defende é tão justa, e a do adversário é tão terrível, que todos os meios para conquistar a vitória e evitar a derrota não são só válidos como necessários. Isso significa que tanto os Estados quanto os insurgentes sentem ter uma justificativa moral para o barbarismo (HOBSBAWM, 2007, p. 127).

Especificamente no concernente à ideologia dos direitos humanos, a disseminação do projeto hegemônico aos países subordinados resultou no aprofundamento de tendências que gradualmente retornavam às relações internacionais. Neste âmbito, o nacionalismo ganhou ânimo renovado no pós-Guerra Fria, fomentado pelas 
intervenções estrangeiras com o ímpeto de reestruturar as sociedades dessas nações (HOBSBAWM, 2007).

Além disso, outro desafio apresentava-se na nova realidade internacional, que se agregava ao tradicional nacionalismo das nações dominadas. Estas mesmas nações são as que presenciaram o desbordamento do poder coercitivo, que passou a ser utilizado amplamente por atores não-estatais, imergindo-as em cenários profundamente violentos. “O que é novo atualmente é que a tecnologia põe nas mãos de indivíduos e grupos transviados poderes que antes eram reservados basicamente aos governos" (NYE, 2009, p. 321). Como consequência desses fenômenos:

$$
\begin{aligned}
& \text { As guerras dentro dos Estados } \\
& \text { fracassados assumem características } \\
& \text { muito diferentes das guerras } \\
& \text { tradicionais e revelam uma mistura } \\
& \text { de conflitos (terrorismo, guerrilha, } \\
& \text { guerra urbana e crime organizado) } \\
& \text { com grande potencial para provocar } \\
& \text { verdadeiros desastres humanitários e } \\
& \text { todos os tipos de ameaças à paz e à } \\
& \text { segurança internacionais (NASSER, } \\
& \text { 2009, p. 121). }
\end{aligned}
$$

Neste contexto, os conflitos nos chamados Estados falidos com intervenção das potências internacionais 
319 | InterAção

tornaram-se úteis para estas em um novo sentido. Atores privados ligados ao setor de segurança beneficiaram-se com os ímpetos intervencionistas, durante a década de 1990 com a justificativa humanitária, e durante os anos 2000 sob o escopo da doutrina de segurança preventiva.

O Estado falido, portanto, tem se transformado em uma instituição conveniente para a ação das grandes potências em que a privatização do uso da força tem repercussões nos níveis internacional e interno (segurança pública) como consequência da cessão do monopólio do uso da força por parte do próprio Estado. Uma das consequências é que Estados e empresas se associam no intuito de acumular riquezas por meio da exploração de recursos naturais, mesclando as categorias tradicionais: civil/militar e privado/público, gerando atores híbridos que trabalham frequentemente com redes informais que favorecem a corrupção e criminalidade (NASSER, 2009, p. 123).

O fenômeno incompreendido pelos precursores do projeto hegemônico estadunidense é a consubstanciação de uma crise global, representando as transformações pelas quais passa a violência política no novo período histórico. 


\section{InterAção}

Elas parecem refletir os profundos desequilíbrios sociais causados em todos os níveis da sociedade pelas alterações mais rápidas e intensas jamais experimentadas pela humanidade, social e individualmente, dentro do período de vida de um ser humano. Elas parecem refletir uma crise dos sistemas tradicionais de autoridade, hegemonia e legitimidade do Ocidente e sua dissolução no Oriente e no Sul, assim como uma crise dos movimentos tradicionais que pretendiam proporcionar alternativas a eles. Elas têm sido exacerbadas pelos fracassos da descolonização em certas regiões do mundo e pelo fim de um sistema internacional estável [...] desde o colapso da União Soviética. E elas se revelarão estar além dos poderes utópicos dos neoconservadores e neoliberais que acreditam na exportação dos valores liberais do Ocidente por meio da expansão dos mercados e das intervenções militares (HOBSBAWM, 2007, p. 137).

Por ende, é possível estabelecermos duas conclusões das análises até aqui efetuadas: o ordenamento internacional surgido com o fim da Guerra Fria, observado com as ferramentas teóricas da teoria crítica coxiana, caracterizou-se pela hegemonia dos Estados Unidos; a contribuição artística de Caetano Veloso acerca de fatores estruturantes dessa ordem internacional é 
321 | InterAção

surpreendentemente reveladora da realidade observada, sendo possível sua aproximação com os aportes da teoria crítica coxiana.

O projeto hegemônico dos Estados Unidos baseou-se em três categorias de ideologias fundamentais: a globalização liberal; a democracia liberal; e os direitos humanos. A utilização de um amplo rol de instituições internacionais para respaldar suas atividades é outro fenômeno que marca sua atuação hegemônica, além das alianças e acordos ad hoc, envolvendo a efetivação de coalizões de Estados no afã de legitimar intervenções e a utilização de meios coercitivos para a consecução de seu projeto. Ademais, as vantagens da potência hegemônica quanto às forças potenciais - especialmente no âmbito militar, onde sua superioridade fora elencada como incontestável (HOBSBAWM, 2007 e KISSINGER, 1999) apenas endossou o quadro que se lhe apresentava. Ainda assim, a atuação das demais potências no novo cenário, não oferecendo elementos de contra-hegemonia, aceitando e, em alguns casos - como da Rússia na Guerra da Bósnia -, esperando a atuação da potência hegemônica, atuando apenas quando seus interesses estavam ameaçados, foram 


\section{InterAção}

fenômenos que dificultaram a estruturação do ordenamento internacional. A estagnação, ou mesmo retrocesso, na aquisição de forças potenciais é um dos fatores que explica tal modo de atuação. Portanto, a década de 1990 postulou dilemas sobremaneira relevantes para as potências mundiais, que na década seguinte tornariam dificultosas e problemáticas as opções unilateralistas tomadas pela potência hegemônica.

[...] por ter sido um período marcado por opções unilateralistas, como a invasão do Iraque, que iriam abalar os alicerces do sistema da legalidade internacional, criando um perigoso precedente no preciso momento em que a globalização dos problemas aconselha às potências o abandono de estratégias individuais e antes recomenda políticas de reforço de solidariedades e colaborações (NEVES; SAMPAIO, 2007, s/p).

Não obstante, quando a potência empreendeu a execução de seu projeto hegemônico, deparou-se com os limites, desafios e dilemas da hegemonia. O principal, amplamente analisado por Cox e Gramsci, diz respeito a manter a utilização do consenso como elemento fundamental, deixando a coerção como elemento marginal, apenas para os casos desviantes. 
323 | InterAção

\section{CONCLUSÃO}

Neste âmbito, Caetano Veloso logrou perceber e apresentar tais fatores em suas canções dos anos 1990 e 2000. As quatro canções aqui analisadas aportam elementos analíticos fundamentais para a compreensão da hegemonia norte-americana, evidenciando que a pretensa nova ordem mundial, liberal, democratizada, globalizada, não efetivava-se do modo como o otimismo liberal esperava. Um amplo rol de ameaças e desafios consolidou-se nesse cenário, inúmeros eventos conflituosos atestaram a permanência da principal característica das relações internacionais, sua complexidade.

O período que seguiu o fim da Guerra Fria testemunhou maior cooperação internacional, especialmente na ONU. Testemunhou também crises globais relacionadas com: mercados financeiros; segurança alimentar; energia; mudanças climáticas; terrorismo; crime transnacional. $\mathrm{O}$ surgimento de numerosos atores não governamentais influentes e alianças inconstantes são também fenômenos dos nossos tempos que fazem a arena internacional um ambiente muito 


\section{InterAção}

mais complexo (AMORIM, 2010, p. 216, tradução nossa).

O início do século XXI demonstrou que as interpretações de Caetano Veloso da realidade internacional, próximas dos apontamentos da teoria crítica coxiana, eram não apenas justificáveis, mas também acertadas. Quando a potência hegemônica foi confrontada, em uma escala muito restrita, é certo, contudo evidenciando que nem mesmo a maior potência militar do mundo estava imune às ações fomentadas pelo aumento da violência e o transbordamento do poder coercitivo para além dos limites do Estado, sua resposta suprimiu o projeto hegemônico em prol dos seus interesses de segurança.

O fim da Guerra Fria e a disseminação transnacional da tecnologia podem produzir uma perspectiva mais ampla de armas nucleares serem usadas em alguns dos novos países que tentam entrar na corrida nuclear do que era o caso no último meio século. E uma das maiores ameaças no futuro será o fato de os terroristas transnacionais obterem armas de destruição em massa. Sabemos que Bin Laden e a rede al Qaeda estiveram fazendo esforços para obter essas armas e fizeram contato com cientistas que 
325 InterAção

trabalhavam no programa nuclear do Paquistão (NYE, 2009, p. 320).

Apreciando a conformação de tal ameaça, e considerando a imprescindibilidade do apoio da população doméstica às ações externas, os formuladores da política externa norte-americana idealizam um cenário de oposições contingentes, visando à cessão de parcela da liberdade em prol da manutenção da segurança.

A instrumentalização do terrorismo em prol da balança de poder americana fez-se, especialmente, por meio da via ideacional, seja ela científica ou discursiva. Para tanto, destaca-se o papel desempenhado pela tragédia, a qual surge como elemento de choque capaz de alterar a balança social entre liberdade e segurança, a favor deste último pendor. Isso é, a população traumatizada dispõe parcela de sua liberdade em troca de maiores níveis de estabilidade, retroalimentando as vias formais de controle público. Logo, à medida que a população concede porções de sua liberdade, o Estado acresce proporcionalmente seu potencial autoritário, alcançando graus elevados de liberdade prática e influência subjetiva (SELIS; GALLO; MASO, 2011, p. 55).

De tal modo, quando o elemento consensual das relações internacionais da potência hegemônica para a 
resolução das problemáticas com que se deparava fora transformado, passando a utilizar-se da doutrina de segurança preventiva, lançando mão dos meios coercitivos para a estabilização do sistema internacional, a ordem hegemônica dissolveu-se. Por conseguinte, o período de análise foco deste trabalho, que marcou o Sistema Internacional pós-Guerra Fria, é delimitado como abarcando desde a derrocada da União Soviética em 1991 até os atentados terroristas de 11 de setembro de 2001. Este período esteve permeado pela atuação dos Estados Unidos como potência hegemônica no novo ordenamento mundial.

\section{REFERÊNCIAS}

ADORNO, Theodor W. Indústria cultural e sociedade. Seleção de textos: Jorge Mattos Brito de Almeida; Tradução: Juba Elisabeth Levy. 5 ed. São Paulo: Paz e Terra, 2009.

AMORIM, Celso. Brazilian Foreign Policy under President Lula (2003-2010): an overview. In: Revista Brasileira de Política Internacional, ano 53, 2010, (special edition) “Emerging Brazil under Lula", p. 214-240. 
327 | InterAção

COX, Robert W. Fuerzas Sociales, Estados y ordenes mundiales: más allá de la teoría de las Relaciones Internacionales. Tradução: Tomás Saraví. Curridabat: Facultad Latinoamericana de Ciencias Sociales (Secretaría General), 1986. pp. 119-196. Reproduzido de: KEOHANE, Robert O. (ed.). Neorealism and its Critics. Nova Iorque: Columbia University Press, 1986.

Gramsci, Hegemony and International

Relations: An Essay in Method. In: GILL, Stephen (ed.). Gramsci, Historical Materialism and International Relations. Cambridge: Cambridge University Press, 1993. pp. 49-66.

FRASER, Nancy. Reconhecimento sem ética? In: Lua Nova, São Paulo, ano 6, n. 70, 2007, p.101-138.

FUKUYAMA, Francis. O fim da história e o último homem. 3. ed. Tradução: Maria Goes. Lisboa: Gradiva, 2007.

GRAMSCI, Antonio. Concepção dialética da história. 3. ed. Tradução: Carlos Nelson Coutinho. Rio de Janeiro: Civilização Brasileira, 1978.

HOBSBAWM, Eric. Era dos extremos: o breve século XX: 1914-1991. 2. ed. Tradução: Marcos Santarrita. São Paulo: Companhia das Letras, 2005.

Globalização, democracia e terrorismo.

Tradução: José Viegas. São Paulo: Companhia das Letras, 2007.

HUNTINGTON, Samuel P. O choque de civilizações e a recomposição da ordem mundial. Rio de Janeiro:

Objetiva, 1997. 
KISSINGER, Henry. Revendo a Nova Ordem Mundial. In: . A Diplomacia das Grandes Potências. 2.ed.

Tradução: Saul S. Gefter e Ann Mary Fighiera Perpétuo. Rio de Janeiro: Livraria Francisco Alves Editora S.A, 1999, p. 881-917.

NASSER, Reginaldo Mattar. Os Estados falidos: novas ameaças e novas oportunidades. In: NASSER, Reginaldo Mattar (Organizador). Os conflitos internacionais em múltiplas dimensões. São Paulo: Editora Unesp, 2009, p. 115-124.

NEVES, José Paulouro das; SAMPAIO, Jorge. Uma década e uma advertência. In: Janus Online, Janus 2007 Religiões e Política Mundial, 2007. Disponível em: <http://www.janusonline.pt/2007/2007_1_1.html>. Acesso em: 20 de novembro de 2013.

NIETZSCHE, Friedrich. O nascimento da tragédia ou helenismo e pessimismo. 2. ed. Tradução: J. Guinsburg. São Paulo: Companhia das Letras, 2001.

NYE, Joseph S. Cooperação e conflito nas relações internacionais. Tradução: Henrique Amat Rêgo Monteiro. São Paulo: Editora Gente, 2009.

O'DONNELL, Guillermo. Democracia, desenvolvimento humano e direitos humanos. In: Debates, Porto Alegre, v.7, n. 1, 2013, p. 15-114.

REIS, Rossana Rocha. Direitos Humanos e conflitos internacionais. In: NASSER, Reginaldo Mattar (Organizador). Os conflitos internacionais em múltiplas dimensões. São Paulo: Editora Unesp, 2009, p. 59-66. 
329 | InterAção

SELIS, Lara Martim R.; GALLO, Rafael Mandagaran; MASO, Tchella Fernandes. O Terrorismo como Agenda das Relações Internacionais: Novos Debates, Velhas Problemáticas. In: Meridiano 47, vol. 12, n. 127, set.-out. 2011, p. 50-57.

TILLY, Charles. Democracia. Petrópolis: Vozes, 2013.

VELOSO, Caetano. Circuladô. Rio de Janeiro: PolyGram, 1991. 1 CD digital, estéreo.

Letras, 1997

Verdade tropical. São Paulo: Companhia das

O mundo não é chato. Organização: Eucanaã Ferraz. São Paulo: Companhia das Letras, 2005.

Cê. São Paulo: Universal Music, 2006. 1 CD

digital, estéreo.

Zii e Zie. São Paulo: Universal Music, 2009. 1

CD digital, estéreo.

VIANA, Manuela Trindade; VILLA, Rafael Antonio

Duarte. Security issues during Lula's administration: from the reactive to the assertive approach. In: Revista

Brasileira de Política Internacional, ano 53, 2010, (special edition) "Emerging Brazil under Lula", p. 91-114.

WISNIK, Guilherme. Caetano Veloso. Coleção Folha Explica. São Paulo: Publifolha, 2005. 
$330 \mid$ InterAção

ANEXOS

\section{Anexo A - Fora de Ordem}

Vapor barato

Um mero serviçal

Do narcotráfico

Foi encontrado na ruína

De uma escola em construção...

Aqui tudo parece

Que era ainda construção

E já é ruína

Tudo é menino, menina

No olho da rua

$\mathrm{O}$ asfalto, a ponte, o viaduto

Ganindo prá lua

Nada continua...

E o cano da pistola

Que as crianças mordem

Reflete todas as cores

Da paisagem da cidade

Que é muito mais bonita

E muito mais intensa

Do que no cartão postal...

Alguma coisa

Está fora da ordem

Fora da nova ordem

Mundial... 
331 | InterAção

Escuras coxas duras

Tuas duas de acrobata mulata

Tua batata da perna moderna

A trupe intrépida em que fluis...

Te encontro em Sampa

De onde mal se vê

Quem sobe ou desce a rampa

Alguma coisa em nossa transa

É quase luz forte demais

Parece pôr tudo à prova

Parece fogo, parece

Parece paz, parece paz...

Pletora de alegria

Um show de Jorge Benjor

Dentro de nós

É muito, é grande

É total...

\begin{abstract}
Alguma coisa
Está fora da ordem

Fora da nova ordem

Mundial...
\end{abstract}

Meu canto esconde-se

Como um bando de Ianomâmis

$\mathrm{Na}$ floresta

$\mathrm{Na}$ minha testa caem

Vem colocar-se plumas

De um velho cocar...

Estou de pé em cima

Do monte de imundo 
Lixo baiano

Cuspo chicletes do ódio

No esgoto exposto do Leblon

Mas retribuo a piscadela

Do garoto de frete

Do Trianon

Eu sei o que é bom...

Eu não espero pelo dia

Em que todos

Os homens concordem

Apenas sei de diversas

Harmonias bonitas

Possíveis sem juízo final...

Alguma coisa

Está fora da ordem

Fora da nova ordem

Mundial...

Composição: Caetano Veloso

In: VELOSO, Caetano. Circuladô. Rio de Janeiro:

PolyGram, 1991. 1 CD digital, estéreo. 
333 | InterAção

\section{Anexo B - Santa Clara, Padroeira da Televisão}

Santa clara, padroeira da televisão

Que o menino de olho esperto saiba ver tudo

Entender certo o sinal certo se perto do encoberto

Falar certo desse perto e do distante porto aberto

Mas calar

Saber lançar-se num claro instante

Santa clara, padroeira da televisão

Que a televisão não seja o inferno, interno, ermo

Um ver no excesso o eterno quase nada (quase nada)

Que a televisão não seja sempre vista

Como a montra condenada, a fenestra sinistra

Mas tomada pelo que ela é

De poesia

Quando a tarde cai onde o meu pai

Me fez e me criou

Ninguém vai saber que cor me dói

E foi e aqui ficou

Santa clara

Saber calar, saber conduzir a oração

Possa o vídeo ser a cobra de outro éden

Porque a queda é uma conquista

E as miríades de imagens suicídio

Possa o vídeo ser o lago onde narciso

Seja um deus que saberá também

Ressuscitar

Possa o mundo ser como aquela ialorixá

A ialorixá que reconhece o orixá no anúncio

Puxa o canto pra o orixá que vê no anúncio 
No caubói, no samurai, no moço nu, na moça nua

No animal, na cor, na pedra, vê na lua, vê na lua

Tantos níveis de sinais que lê

E segue inteira

Lua clara, trilha, sina

Brilha, ensina-me a te ver

Lua, lua, continua em mim

Luar, no ar, na tv

São Francisco

Composição: Caetano Veloso

In: VELOSO, Caetano. Circuladô. Rio de Janeiro:

PolyGram, 1991. 1 CD digital, estéreo. 
335 | InterAção

\section{Anexo C - O Heroi}

Nasci num lugar que virou favela

Cresci num lugar que já era

Mas cresci a vera

Fiquei gigante, valente, inteligente

Por um triz não sou bandido

Sempre quis tudo o que desmente esse país

Encardido

Descobri cedo que o caminho

Não era subir num pódio mundial

E virar um rico olímpico e sozinho

Mas fomentar aqui o ódio racial

A separação nítida entre as raças

Um olho na bíblia, outro na pistola

Encher os corações e encher as praças

Com meu guevara e minha coca-cola

Não quero jogar bola pra esses ratos

Já fui mulato, eu sou uma legião de ex mulatos

Quero ser negro $100 \%$, americano,

Sul-africano, tudo menos o santo

Que a brisa do Brasil beija e balança

E no entanto, durante a dança

Depois do fim do medo e da esperança

Depois de arrebanhar o marginal, a puta

O evangélico e o policial

Vi que o meu desenho de mim

É tal e qual

O personagem pra quem eu cria que sempre

Olharia

Com desdém total

Mas não é assim comigo.

É como em plena glória espiritual

Que digo: 
Eu sou o homem cordial

Que vim para instaurar a democracia racial

Eu sou o homem cordial

Que vim para afirmar a democracia racial

Eu sou o herói

Só Deus e eu sabemos como dói

Composição: Caetano Veloso

In: VELOSO, Caetano. Cê. São Paulo: Universal Music, 2006. 1 CD digital, estéreo. 
337 | InterAção

Anexo D - A Base de Guantánamo

O fato dos americanos

Desrespeitarem

Os direitos humanos

Em solo cubano

É por demais forte

Simbolicamente

Para eu não me abalar
A base de Guantánamo
A base
Da baía de Guantánamo
A base de Guantánamo
Guantánamo

Composição: Caetano Veloso

In: VELOSO, Caetano. Zii e Zie. São Paulo: Universal Music, 2009. 1 CD digital, estéreo. 